\title{
Moodle Learning System as an Effective Tool for Implementing the Innovation Policy of the University
}

\author{
Alfiya Sibgatullina, Elabuga Institute, Kazan Federal University, Russia \\ Rimma Ivanova, Linguistics University, Nizhny Novgorod, Russia* \\ Elena Yushchik, Far Eastern State Technical Fisheries University, Russia
}

\begin{abstract}
The current study examines the Moodle learning management system as an effective tool for implementing the innovation policy of the university. For this, the following methods are employed: (1) monitoring of the Best Global Universities 2020 ranking results in the context of Moodle webanalytics, (2) evaluation of advantages attributed to innovative education, (3) survey of students and teachers aimed at assessing their perceptions toward the use of Moodle. The conducted study revealed that the current focus of the world's leading universities is set on online learning, in particular, carried out by means of innovative learning platform Moodle. Feedback regarding the quality of education in the Moodle environment received from the parties directly related to the educational process has provided an insight into the effectiveness of innovative education. The collected results can be useful for the integration of Moodle into university education and innovative learning promotion to create a space for competitive and high-quality instruction.
\end{abstract}

\section{KEYWORDS}

Higher Educational Establishment, Innovation, Online Education, Pedagogy, Virtual Platform

\section{INTRODUCTION}

Didactic methods have undergone substantial changes over the past decade. The education paradigm shifted from conventional teaching to independent learning (Dobrydina et al., 2014). Distance education is becoming increasingly popular around the world (Luk et al., 2018; Zhienbayeva \& Tapalova, 2014). In these circumstances, e-learning market offers great investment opportunities at both the macro and micro levels (Veselitsky \& Khabarov, 2019), as well as services widely used by various institutions (Golitsyna, 2017). The introduction of innovations in education allows teachers to provide students with a broader range of educational services, from the creation of online learning content to distribution of thereof, all with the involvement of highly qualified teachers who create and distribute the training courses (Goyal \& Tambe, 2015). 


\section{Background}

In the context of continuing globalization, colleges and universities must learn to quickly adapt and produce on-demand specialists (Yushchik, 2013). The rise of online learning motivated universities and colleges to integrate smart equipment (Chootongchai \& Songkram, 2018). As a result, there are many software options available in this area, including commercial services and open-source tools such as:

- Blackboard - a business-oriented multifunctional platform to manage corporate training, but with some drawbacks (opaque price, limited direct support, no Android app);

- Moodle - a smartphone-friendly open-source learning management system (LMS) and platform for blended learning and online courses that has an extensive feature set (interaction with content, multiple-choice questions, built-in text editor, support for third-party cloud storage providers (Dropbox) to submit assignments, support for multiple languages, open standards (SCORM Sharable Content Object Reference Model), etc.);

- Zoom - a cloud-based platform that focuses on video conferencing quality and has both a free use version with a time limit (40 minutes) and a commercial version;

- Microsoft Teams - a platform that focuses on team collaboration in Microsoft 365 and Office 365, which integrates document sharing, online meetings, meeting scheduling, and other features, making communication easier and more efficient (Dalton et al., 2021; Luna, 2020).

Considering that Moodle LMS has the largest set of features and is open-source, it can be deemed one of the most flexible and powerful platforms. In 2021, there were more than 183875 sites running on Moodle that have been registered from 424 countries (Moodle, 2021b). The advantage of this system is that it facilitates social constructivism (Anand \& Eswaran, 2018), which means that Moodle promotes social interaction and active learning. In addition to that, with information technologies (ITs) come different types of users, including students, parents, teachers, university administration, politicians, and instructional staff, who renovate and enhance the learning process (Vu et al., 2017). The trend towards learning using advanced technologies accelerated in a situation of higher education anti-crisis management undertaken against the background of COVID-19. The worldwide spread of coronavirus infection has led to the need to adapt learning methodologies to an online format due to the impossibility of conducting classes offline, providing educational stakeholders with physical mobility and virtual exchange within a safe environment (International Association of Universities, 2021).

As practice shows, what matters in the context of international cooperation is not the amount of information learned, which is emphasized by constructivism, but the approach to knowledge creation, learning, and understanding due to the importance of the social and cultural dimension, which is emphasized by social constructivism (Rytilä, 2021). The biggest takeaway from teaching international audiences is that teaching cannot be simplified to the transfer of knowledge from a teacher to a student (Balım et al., 2007). Instead, it must be part of institutional reality and maintain its functioning through collective recognition. In this light, developing effective teaching and learning strategies is of paramount importance (Moussiaux \& Norman, 2003). At the same time, information does not exist without a person who could make sense of what he or she learns. It is when we arrive at the theory of social constructivism. A constructivist learning environment has several distinctive features (Andreev et al., 2008; Finnegan \& Ginty, 2019):

(1) knowledge comes not only from teachers but also from students;

(2) feedback drives performance;

(3) social experience facilitates learning;

(4) teachers and students learn to appreciate multiple perspectives and build their communication accordingly; 
(5) activities, tools, and environments are designed to meet the needs of students. If those needs change, then everything else will change too.

Social constructivism, first proposed by Lev Vygotsky, is a process in which an individual interacts with the socio-cultural environment; during this interaction, an individual and his/her socio-cultural environment complement each other (Özden, 2021). Martin Dugiamas, the founder of Moodle, turned out to be a follower of the Soviet psychologist. The first version of Moodle saw the light in 2002. Today, Moodle is used by $60 \%$ of educational institutions around the world, the United Nations, and even Google (OE Global, 2021).

Moodle has many advantages, among which availability and ease of access to learning materials anytime, anywhere; collection of all learning materials in one place; and rapid feedback through Internet tools (Goyal \& Tambe, 2015). Despite the potential Moodle has as a learning platform, any innovation is doomed to fail at the first run (Baldoni, 2017). The reasons could be reliance on poor marketing strategies, poor service and insufficient technical support, and unskilled teaching staff (Vershitskaya et al., 2019). Another issue is that many applicants have doubts if distance learning is the correct option for them. It could result from a subconscious distrust in everything new. Nevertheless, many universities around the world continue to support blended and distance learning (Gakhovich \& Savchenko, 2018; Kavitha \& Jaisingh, 2018).

In 2021, Moodle is a learning platform of choice for educational organizations across 247 countries in the world. Most are concentrated in these 10 countries: Spain, the United States, Mexico, Germany, Brazil, France, India, Indonesia, Colombia, and the Russian Federation. By 2021, platform had added more users passing the 200 million mark (Moodle, 2021a). Therefore, one can expect distance learning to become the dominant form of education. An important step university must take to make an innovation policy work is to invest in infrastructure, as this will enable effective teaching and scientific cooperation with other universities around the world (Orús et al., 2016).

The novelty of this study lies in the fact that it represents a synthesis of new evidence on the effect of innovative technologies' implementation in higher education, focusing on three thematic areas: teaching and learning within the university community, social reality of human activity and digital technology, and flexibility of university management activities.

The practical contribution of this paper stems from the fact that it provides an information base for digital learning implementation, therefore promoting remote and virtual education as a dynamic learning option responding to the demands of the economy and society and strengthening equity in a globalized world through the formation of a knowledge-based society.

The scientific contribution of this work is in synthesized inferences concerning the assessment of academic changes occurring in the university community as well as brought forward consideration of feedback as a tool for building effective communication within the framework of managing innovation policy of a university.

Overall, this study is divided into five sections. Section 1 is devoted to the literature review and justification of the relevance of the chosen topic. Section 2 presents research methodology and materials on the basis of which the study was carried out. Section 3 describes the authors' vision of the problem by summarizing available statistical data on the matter. Section 4 is a discussion. Here the inferences made are compared with those of other investigators. The final section stands for conclusions. It summarizes the collected findings, prescribes their practical implementation, and outlines future work direction.

The aim of this study is to investigate how Moodle can assist the renewal of university education. For this, the following objectives are to be accomplished:

1. monitor the process of university education conducted by means of the Moodle LMS;

2. highlight the main differences between offline and online education formats from the perspective of higher education; 
3. study the impact of online education in the context of university innovation policy.

\section{Materials and Methods}

This study looks at the best universities of Europe, Asia, and the Russian Federation within the limits of their position in the Best Global Universities ranking (UN News, 2020) and descriptive statistics of Moodle (2021a). The Best Global Universities ranking is a snapshot of academics' opinion on how universities around the world and in the region stand globally and regionally. In 2020, the Best Global Universities ranking revealed the top 1500 universities from around the world, covering 81 countries. It uses 13 basic and their weights: global research reputation (12.5\%), regional research reputation (12.5\%), publications (10\%), books (2.5\%), conferences $(2.5 \%)$, normalized citation impact $(10 \%)$, total citations $(7.5 \%)$, number of publications that are among the $10 \%$ most cited $(12.5 \%)$, percentage of total publications that are among the $10 \%$ most cited (10\%), international collaboration relative to country $(5 \%)$, international collaboration $(5 \%)$, number of highly cited papers that are among the $1 \%$ most cited in their field (5\%), and percentage of total publications that are among the $1 \%$ most highly cited papers (5\%). As concerns the Moodle statistics, it provided data on the number of registered Moodle sites at the national level.

Monitoring the quality of higher education through the 2020 Best Global Universities ranking system and Moodle web analytics (Moodle, 2021a) provided information on academic changes in the university community, which contributed to the comparison of offline and online education as a knowledge acquisition format (Marinoni et al., 2020; Vu et al., 2017). The determination of the characteristics of each type was made via systematization and analysis of statistical information (International Association of Universities, 2021) in the MS Excel and its Data Analysis add-on according to three parameters:

(1) percentage of higher education institutions that have replaced offline instruction with distance teaching and learning;

(2) percentage of higher education institutions working to develop solutions to continue teaching and learning through digital technology or self-study tools;

(3) percentage of higher education institutions with a traditional learning format.

The collected data were visualized as a ring chart of interval series of variation distribution in the context of a model of meaningful differences between offline and online learning, given the new Covid-resulted paradigm of the world. In order to further achieve progress in innovative education, the analysis conducted was supplemented with a feedback tool - online surveys conducted under the questionnaire method (Appendix A) and targeting students and teachers, two main parties of interest in the educational process. The time when the survey was held coincides with the peak of the worldwide COVID spread (2020).

As research participants, a total of 200 respondents (56\% women) was involved. A small sample size allows obtaining results faster and with less cost. Respondents were grouped into two categories: students $(n=180)$ and teachers $(n=20)$ from Asian universities. Students, aged 21 to 25 years, were enrolled in the Faculty of Pharmaceutical Management, Biotechnology Management programs, and the Faculty of Finance. Almost none of them had any experience with the Moodle prior to enrollment. Teachers were 34 years of age and had some experience of Moodle at the time of the survey. All participants had high technical skills related to information technologies. By high technical skills, this study means knowledge of the computer organization and its functions, possessing skills enough to use computer and similar devices, and awareness of the role of such devices in the daily life of a modern person.

The experiment comprises the following three stages: 
(1) conducting an anonymous survey using a specially designed questionnaire. The questionnaire contained yes/no statements with which the respondents were asked whether they consider the Moodle learning platform having a simple interface, being easy to learn, being a good source of learning materials, and being supportive to learner's collaborative and learning abilities. The questionnaire was meant to explore the perceptions of students and teachers on the use of Moodle;

(2) analysis of survey results using the matrix method. Each cell of the matrix table contains "+" or "-" and based on the answers in the column, comparisons are made between the groups;

(3) drawing conclusions. Answers that are the same between the two groups of respondents ("+" / "+" or "-" / "-") symbolize the identity in the views on the problem of practice under study; answers that do not match between the two groups ("“+" / "-" or vice versa) symbolize no identity, respectively.

The results of the survey, summarized as a matrix table, made it possible to highlight practicerelated issues that hinder the effective use of Moodle in the teaching and learning process. The methodological basis for the study was the concepts of Vu et al. (2017), Finnegan and Ginty (2019), and Marinoni et al. (2020). Data needed for the research process were taken from such international databases as Best Global Universities (UN News, 2020), Moodle (2021b), and International Association of Universities (2021). The methods used encompass monitoring, web analytics, metaanalysis, and questionnaires.

The central research limitation is that the analysis of the results includes the assessment of the online survey outcomes, which gives the inferences made a subjective nature that is prone to change.

\section{Results}

Universities integrate innovations to update learning environments, so that students could access learnings materials without the need to attend classes. Innovative solutions are widely-known to facilitate continuous learning and make the learning process more attractive and comfortable. As a result, Moodle has become one of the most popular and effective knowledge production and dissemination learning management systems used by academic institutions to upgrade themselves, especially during the impact of the COVID-19 pandemic, when a sudden shift of universities to distance education occurred.

Table 1 presents top universities across the US, Europe, Asia, and the Russian Federation based on the UN News' Best Global Universities ranking and statistics on the use of the Moodle platform.

As can be seen in Table 1 above, British and American universities are among the top 20 best universities in the world, whereas universities in Singapore and China are among the top 50 best universities. The best universities in the Russian Federation are Lomonosov Moscow State University (ranks $266^{\text {th }}$ out of 1069 in the global ranking), National Research Nuclear University MEPhI (ranks $388^{\text {th }}$ ), Moscow Institute of Physics and Technology (ranks $402^{\text {nd }}$ ). It is important to note that all countries have IT infrastructure for the production and dissemination of knowledge, which is particularly relevant in the era of COVID-19 for adequate communication and information exchange between students and educators as well as safe learning environment. The largest number of registered Moodle sites is in the US (13 777), whereas the lowest falls upon Singapore (359). The Russian Federation holds an average position on innovative education implementation among the analyzed countries, the number of registered Moodle sites there is 5918 or $43 \%$ of that of the US, the innovation policy leader in the educational segment. Hence, it can be inferred that the traditional learning environment is losing its monopoly in education, while the innovativeness gains momentum and expands educational services through the use of Moodle LMS, which characterizes it as one of the inclusive learning platforms in online education.

In general, the Moodle platform has several advantages over traditional learning environments and a reputation stemming from the academic community's values of freedom, peer review, and knowledge sharing. On top of this, it is applicable in countries with different levels of economic 
Table 1. Monitoring of education in the digital context, as of 2020

\begin{tabular}{|c|c|c|c|c|}
\hline Region & University & $\begin{array}{l}\text { Regional } \\
\text { rank }\end{array}$ & Global rank & $\begin{array}{l}\text { Number of registered } \\
\text { Moodle sites }\end{array}$ \\
\hline \multirow[t]{3}{*}{ Asia } & National University of Singapore & 1 & 34 & \multirow{3}{*}{$\begin{array}{l}\text { Singapore: } 359 \\
\text { China: } 573\end{array}$} \\
\hline & Tsinghua University (China) & 2 & 36 & \\
\hline & $\begin{array}{l}\text { Nanyang Technological University } \\
\text { (Singapore) }\end{array}$ & 3 & 43 & \\
\hline \multirow[t]{3}{*}{ Europe } & University of Oxford (UK) & 1 & 5 & \multirow{3}{*}{ UK: 4787} \\
\hline & University of Cambridge (UK) & 2 & 9 & \\
\hline & Imperial College London (UK) & 3 & 20 & \\
\hline \multirow[t]{3}{*}{ USA } & Harvard University (US) & 1 & 1 & \multirow{3}{*}{ US: 13777} \\
\hline & $\begin{array}{l}\text { Massachusetts Institute of Technology } \\
\text { (US) }\end{array}$ & 2 & 2 & \\
\hline & Stanford University (US) & 3 & 3 & \\
\hline \multicolumn{5}{|c|}{ Russian universities in international ranking } \\
\hline \multirow{3}{*}{$\begin{array}{l}\text { Russian } \\
\text { Federation }\end{array}$} & Lomonosov Moscow State University & 1 & 266 & \multirow{3}{*}{$\begin{array}{l}\text { Russian Federation: } \\
5918\end{array}$} \\
\hline & $\begin{array}{l}\text { National Research Nuclear University } \\
\text { MEPhI (Moscow Engineering Physics } \\
\text { Institute) }\end{array}$ & 2 & 388 & \\
\hline & $\begin{array}{l}\text { Moscow Institute of Physics and } \\
\text { Technology }\end{array}$ & 3 & 402 & \\
\hline
\end{tabular}

Source: adapted from Moodle (2021b), Top Universities (2021), and UN News (2020).

development and promotes educational practices through the creation of collaborative learning in a globalized world. With respect to the above, comparison of the possibilities of distance education with the traditional in-class environment (especially against the background of the new COVID-19 era) as well as consideration of the shares of higher education institutions adhering to one or another instruction mode is interesting (Figure 1).

Figure 1. Opportunities offered by in-person and online education.

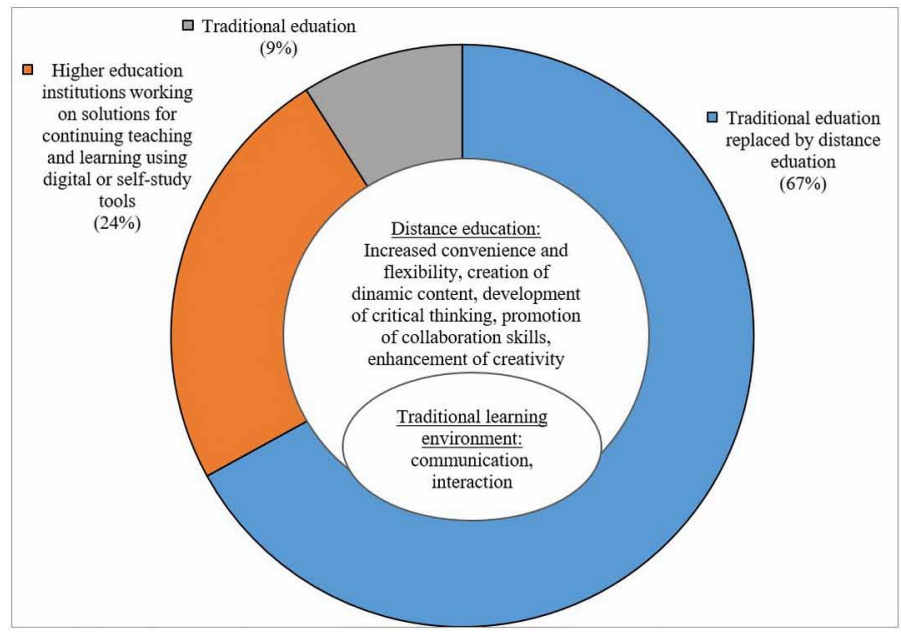


Source: developed by the authors based on data adapted from International Association of Universities (2021)

As shown in the figure above, in more than half of higher education institutions $(67 \%)$ traditional classrooms were replaced by distance learning. In almost a quarter (24\%), management and administration are only working to develop solutions to continue teaching and learning through digital technology or self-study tools. Finally, the traditional knowledge provision format is now supported by only $9 \%$ of higher education institutions. These data indicate that digital transformation in education is occurring through educational technologies. This trend requires digital literacy from educational stakeholders and adequate IT infrastructure as a technological basis for knowledge delivery. To achieve effective deployment of Moodle, educators must overcome barriers to quality education in a Moodle-based setting. A Moodle perception survey (Appendix A) revealed that 35\% of respondents believe that Moodle is time-demanding and hard to use (Table 2). While a quarter of respondents experienced problems related to network performance and bandwidth, $10 \%$ said they had poor technical support. Over $50 \%$ of respondents reported having no interest in doing extra work. Overall, $80 \%$ gave a positive feedback for Moodle deployment and reported an improvement in the learning and planning of learning activities.

Table 2. Matrix of barriers to Moodle-assisted learning.

\begin{tabular}{|l|l|l|l|l|l|}
\hline User & Extra work & $\begin{array}{l}\text { Did not like the } \\
\text { technology }\end{array}$ & $\begin{array}{l}\text { Network and } \\
\text { bandwidth } \\
\text { issues }\end{array}$ & $\begin{array}{l}\text { Lack technical } \\
\text { support they } \\
\text { need }\end{array}$ & Low motivation \\
\hline Students & + & + & + & + & + \\
\hline Teachers & + & + & + & + & - \\
\hline
\end{tabular}

Source: developed by the authors

As can be seen, students and teachers had similar Moodle-related issues, which is a positive signal as it shows that they have the same understanding of the barriers to the studied problem of practice. The only difference was that students had little motivation to interact with Moodle independently, while teachers were more motivated. On the whole, the use of Moodle for educational purposes has a favorable impact on the formation of a knowledge-based society and contributes to the innovation policy of a higher education institution either through institutional leadership or through educational service users. The evidence for the effectiveness of the use of the considered educational technology in learning is its international recognition (use by top-ranked world universities) and global demand.

\section{Discussion}

The results of the conducted investigation showed that the use of modern educational technologies in a globalized world is important for both developed economies taking high positions in global educationrelated rankings (World Bank, 2018) and developing ones facing the challenges of providing highquality higher education to as many people as possible at the lowest possible cost. The integration of LMS technologies in education can solve each of these issues by bringing together in-class and online learning. The collected data evidence that among the countries analyzed, the US holds the leading position in terms of innovative education. This country most often uses Moodle LMS to promote knowledge in pedagogy. The findings of Lima (2021) are fully consistent with these conclusions. More precisely, she argues that Moodle software is highly effective in the production and dissemination of knowledge, but currently, there are some barriers that make it difficult for a person to access the distance format. The foremost of them are the Internet access quality, especially in developing states, and the prejudice among the population regarding the effectiveness of distance education. 
Varnika (2018) states that the benefits of using Moodle LMS for e-learning are grounded on nine principles: quality, reliability, security, support, stability, enlightenment, benchmarking, cost effectiveness, and cloud computing. The last principle (cloud computing) can allow the product created in developing countries to be part of the Western developed countries and be a factor of cheaper production with a high economic value, which is beneficial to developing economies. This study found that online education allows knowledge recovery, dynamic content creation, creative and critical thinking development, and collaborative skills acquisition as the learning process takes place in a didactic and pedagogical environment simultaneously. The listed advantages of online education provide 24/7 access to the learning material, easiness of interaction due to constant and unlimited access to Internet facilities, reinforced learning, and no need to go to the library.

The inferences made within the conducted research also have much in common with the work of Anand and Eswaran (2018), who argue that Moodle LMS facilitates the innovation policy of universities and supports the needs of teachers (course planning and delivery in different formats, such video, audio, presentation, and text), students (learning, listening, visualization, evaluation), as well as interaction between different users. Precisely this makes education interactive and inclusive (Kerimbayev et al., 2017). Correspondingly, it can be argued that the introduction of digital technologies into the field of pedagogy will make higher education more efficient and effective and reduce social inequality (Chourish et al., 2016; Khairani et al., 2019).

Lately, a great deal of attention has been given to identifying barriers in students' distance learning in order to adapt technology to the new possibilities of the world paradigm (Lima, 2021). To investigate the matter of the learning process harmonization through the use of Moodle, this study turned to the method of an online survey. This enabled uncovering that the major obstacle toward using Moodle by students is their low motivation to learn independently associated with the considerable physical distance between them and an educator (Falleiro, 2013; Kataoka \& Mertala, 2017). The outcomes of Shchedrina et al. (2021), whose work concentrates upon the ways to make Moodle courses adaptable and thus enhance the learning process, are also in good agreement with the results of the carried-out survey. More precisely, by collecting feedbacks, researchers found that the majority of their study participants had difficulty with self-education and comprehending learning material given on audio recordings.

Summarizing the results collected within the current investigation, one can confidently infer that Moodle LMS is an accessible and economically justified option for universities to upgrade their learning and teaching environments. This online learning platform follows the principle of social constructivism by supporting the exchange of experience between learners, as well as mutual understanding between representatives of different countries (Kerimbayev et al., 2017). Against the backdrop of the effects of the COVID-19 crisis, distance learning mode has made education more accessible to the population, which boosted the positive attitude to this form of education in society, counterbalancing the expert criticism that has recently increased in many countries (Marinoni et al., 2020). However, despite the usefulness and cost-effectiveness of the investigated platform, the demand for educational process improvement with relevant and effective educational technologies is yet to be met fully.

\section{Conclusion}

This study assessed Moodle as a distance education tool designed to provide affordable high-quality education to various segments of the population anywhere, anytime. It unveiled that deploying Moodle not only improves the quality of education by eliminating the monotony of learning but also reduces its cost due to the virtual information exchange and no need to hold traditional classes, which makes e-learning a more preferred mode of knowledge delivery than those we traditionally relied on. University integrating e-learning tools, including Moodle, were proved to increase their prestige globally through the university community. In view of this, it can be stated that learning management platforms have become a key driver of education development amid the new COVID-resulted world 
paradigm. A perception survey conducted to determine how students and teachers feel about using Moodle showed the need to instruct both user categories on how to use Moodle effectively. Moreover, while doing so, an exceptional emphasis should be set on methodological improvement on the part of academic administration to increase students' learning motivation. The results of the study may be of use in regions with a shortage of skilled teaching staff, problems with social, economic, or transport infrastructure, skilled teaching staff, education inequality.

Future research work is recommended to be connected with the search for tools to assess the quality of online education at colleges and universities while considering the experience of countries with different development levels.

\section{ACKNOWLEDGMENT}

Alfiya Sibgatullina has been supported by the Kazan Federal University Strategic Academic Leadership Program. 


\section{REFERENCES}

Anand, A., \& Eswaran, S. (2018). Case study MOODLE: Approach to Learning and Content Management System (LCMS). International Journal on Computer Science and Engineering, 6(7), 1147-1152.

Andreev, A. V., Andreeva, S. V., \& Dotsenko, I. B. (2008). eLearning practice using Moodle. Taganrog: TTI SFU.

Baldoni, J. (2017). Lead with purpose: Giving your organization a reason to believe in itself. Hertogenbosch: AMACOM.

Balım, A., İnel, D., \& Evrekli, E. (2007). Probleme dayalı öğrenme (PTÖ) yönteminin kavram karikatürleriyle birlikte kullanımı: Fen ve teknoloji dersi etkinliği. Proceedings of the international educational technologies conference.

Chootongchai, S., \& Songkram, N. (2018). Design and development of SECI and Moodle online learning systems to enhance thinking and innovation skills for higher education learners. International Journal of Emerging Technologies in Learning, 13(3), 154-172. doi:10.3991/ijet.v13i03.7991

Chourish, D., Buttan, C. K., Chaurasia, A., \& Soni, A. (2016). Effective e-learning through Moodle. International Journal of Advanced Technology and Engineering Research, 1(1), 34-38.

Dalton, W., Turner, B., \& DeMuro, J. (2021). Best online learning platforms of 2021. TechRadar. Retrieved 15/11/2021, from https://www.techradar.com/best/best-online-learning-platforms

Dobrydina, T. I., Maslennikova, O. G., \& Nadezhdina, E. Y. (2014). Prospects for using the virtual learning platform MOODLE in teaching foreign languages. Bulletin of Kemerovo State University, 2/3(59), 282-287.

Falleiro, S. (2013). MOODLE-LMS as an innovative and cost effective E-learning tool for open and distance learning. Pan-Commonwealth Forum, 7, 1-7.

Finnegan, M., \& Ginty, C. (2019). Moodle and social constructivism: Is Moodle being used as constructed? A case study analysis of Moodle use in teaching and learning in an Irish Higher Educational Institute. All Ireland Journal of Higher Education, 11(1), 1-21.

Gakhovich, S., \& Savchenko, T. (2018). Implementation of distance learning based on the MOODLE software environment. Kyiv National University of Trade and Economics.

Global, O. E. (2021). Open Education Consortium. Retrieved 13/04/2021, from https://www.oeconsortium.org/ about-oec/board-of-directors/martin-dougiamas/

Golitsyna, I. (2017). Educational process in electronic information-educational environment. Procedia: Social and Behavioral Sciences, 273, 939-944. doi:10.1016/j.sbspro.2017.02.132

Goyal, E., \& Tambe, S. (2015). Effectiveness of MOODLE-enabled blended learning in private Indian business school teaching niche programs. The Online Journal of New Horizons in Education, 5(2), 14-22.

International Association of Universities. (2021). COVID-19: Higher Education challenges and responses. Retrieved 10/11/2021, from https://www.iau-aiu.net/COVID-19-Higher-Education-challenges-and-responses

Kataoka, H., \& Mertala, M. (2017). The role of educators and their challenges in distance learning in new millennium. Palma Journal, 16(3), 423-426. 10.1177\%2F0047239516661713

Kavitha, R., \& Jaisingh, W. (2018). A study on the student experiences in blended learning environments. International Journal of Recent Technology and Engineering, 7(4S), 183-186.

Kerimbayev, N., Kultan, J., Abdykarimova, S., \& Akramova, A. (2017). LMS Moodle: Distance international education in cooperation of higher education institutions of different countries. Education and Information Technologies, 22(5), 2125-2139. doi:10.1007/s10639-016-9534-5

Khairani, N. A., Rajagukguk, J., \& Derlina. (2019). Development of Moodle E-Learning media in industrial revolution 4.0 Era. In 4th Annual International Seminar on Transformative Education and Educational Leadership (AISTEEL 2019) (pp. 752-758). Atlantis Press. 10.2991/aisteel-19.2019.172 
Lima, J. (2021). Moodle Platform: Education through technological mediation. Revista Científica Multidisciplinar Núcleo do Conhecimento. Retrieved 09/11/2021, from https://www.nucleodoconhecimento.com.br/education/ moodle-platform

Luk, C., Ng, K., \& Lam, W. (2018). The acceptance of using open-source learning platform (Moodle) for learning in Hong Kong's higher education. In International Conference on Technology in Education (pp. 249257). doi:10.1007/978-981-13-0008-0_23

Luna, S. (2020). Microsoft teams VS Zoom in online learning: a side-by-side comparison. ELearningInside. Retrieved 09/11/2021, from https://news.elearninginside.com/microsoft-teams-vs-zoom-in-online-learning-aside-by-side-comparison/

Marinoni, G., Land, H., \& Jensen, T. (2020). The impact of COVID-19 on Higher Education around the world. IAU Global Survey Report. International Association of Universities.

Moodle. (2021a). Official website. Retrieved 13/04/2021, from https://stats.moodle.org/

Moodle. (2021b). Moodle statistics. https://stats.moodle.org/sites/index.php?country=RU

Moussiaux, S., \& Norman, J. (2003). Constructivist teaching practices: Perceptions of teachers and students. Collected Works Conference Proceedings, 21, 661-687.

News, U. N. (2020). How U.S. News Calculated the Best Global Universities Rankings. Retrieved 13/04/2021, from https://www.usnews.com/education/best-global-universities/articles/methodology

Orús, C., Barlés, M. J., Belanche, D., Casaló, L., Fraj, E., \& Gurrea, R. (2016). The effects of learner-generated videos for YouTube on learning outcomes and satisfaction. Computers \& Education, 95, 254-269. doi:10.1016/j. compedu.2016.01.007

Özden, Y. (2021). Öğrenme ve öğretme. Pegem Akademik.

Rytilä, J. (2021). Social constructivism in mathematics? The promise and shortcomings of Julian Cole's institutional account. Synthese, 199(3-4), 11517-11540. doi:10.1007/s11229-021-03300-7

Shchedrina, E., Valiev, I., Sabirova, F., \& Babaskin, D. (2021). Providing adaptivity in Moodle LMS courses. International Journal of Emerging Technologies in Learning, 16(2), 95-107. doi:10.3991/ijet.v16i02.18813

Top Universities. (2021). QS World University Rankings. Retrieved 13/04/2021, from https://www.topuniversities. com/university-rankings/employability-rankings/2020

Varnika, V. (2018). Cloud computing advantages and challenges for developing nations. International Journal of Scientific Research in Computer Science and Engineering, 6(3), 51-55. doi:10.26438/ijsrcse/v6i3.5155

Vershitskaya, E., Mikhaylova, A., Gilmanshina, S., Dorozhkin, E., \& Epaneshnikov, V. (2019). Present-day management of universities in Russia: Prospects and challenges of e-learning. Education and Information Technologies. Berlin: Springer Science+Business Media.

Veselitsky, O., \& Khabarov, D. (2019). Developmental trends in distance education in Russia and abroad. Colloquium Journal, 3(27), 1-3.

Vu, P., Fredrickson, S., \& Moore, C. (2017). Handbook of Research on Innovative Pedagogies and Technologies for Online Learning in Higher Education. IGI Global. doi:10.4018/978-1-5225-1851-8

World Bank. (2018). Gross national income per capita 2018, Atlas method and PPP. Retrieved 13/04/2021, from https://databank.worldbank.org/data/download/GNIPC.pdf

Yushchik, E. V. (2013). Formation of a database of tasks in a test form in the automated knowledge control system of the Fisheries University. Bulletin of the Far Eastern Regional Educational and Methodological Center, 20, 201-205.

Zhienbayeva, N. B., \& Tapalova, O. B. (2014). Integral model of communicative subject of modern education. World Applied Sciences Journal, 30(12), 1821-1825. doi:10.5829/idosi.wasj.2014.30.12.14273 


\section{APPENDIX 1}

\section{Questionnaire form}

Read the following statements. Chose an answer on a binary scale (Yes or No) to indicate whether you agree or disagree with the given statement.

1. Moodle has a simple interface: YES / NO

2. The version of Moodle I used during the course is enough for me to start using Moodle: YES / NO

3. Moodle helped me access (or create) all the learning material I (students) needed: YES / NO

4. Moodle helped me better communicate with the instructor (students): YES / NO

5. Moodle helped me better communicate and collaborate with my classmates (colleagues): YES / NO

6. Moodle helped me to receive immediate feedback from the instructor (students): YES / NO

7. Accessibility of Moodle motivates me to learn independently: YES / NO

8. Based on all the above features, I feel that Moodle is an effective educational tool: YES / NO

Alfiya Sibgatullina is a leading researcher, PhD of Pedagogical Sciences, who now works as an Assistant Professor of the Department of German Philology in Elabuga Institute, Kazan Federal University in Russian Federation. Alfiya Sibgatullina has been supported by the Kazan Federal University Strategic Academic Leadership Program.

Rimma Ivanova is a leading researcher, PhD in Philology, now works as an Associate Professor at the Institute of Distance Learning in Linguistics University Nizhny Novgorod in Russia. 